\title{
Transatlantica
}

Revue d'études américaines. American Studies Journal

\section{“Tomato packers recess, Copiah County, 1936"}

Photographs, p. 31

\section{Louis Mazzari}

\section{(2) OpenEdition}

Journals

Electronic version

URL: https://journals.openedition.org/transatlantica/4562

DOI: 10.4000/transatlantica.4562

ISSN: $1765-2766$

\section{Publisher}

Association française d'Etudes Américaines (AFEA)

Electronic reference

Louis Mazzari, "'Tomato packers recess, Copiah County, 1936"'”, Transatlantica [Online], 2 | 2009, Online since 01 February 2010, connection on 02 February 2023. URL: http://journals.openedition.org/ transatlantica/4562 ; DOI: https://doi.org/10.4000/transatlantica.4562

This text was automatically generated on 2 February 2023.

\section{(c) (ㅇ) $\odot$}

Creative Commons - Attribution-NonCommercial-NoDerivatives 4.0 International - CC BY-NC-ND 4.0 https://creativecommons.org/licenses/by-nc-nd/4.0/ 


\section{"Tomato packers recess, Copiah County, 1936"}

Photographs, p. 31

Louis Mazzari

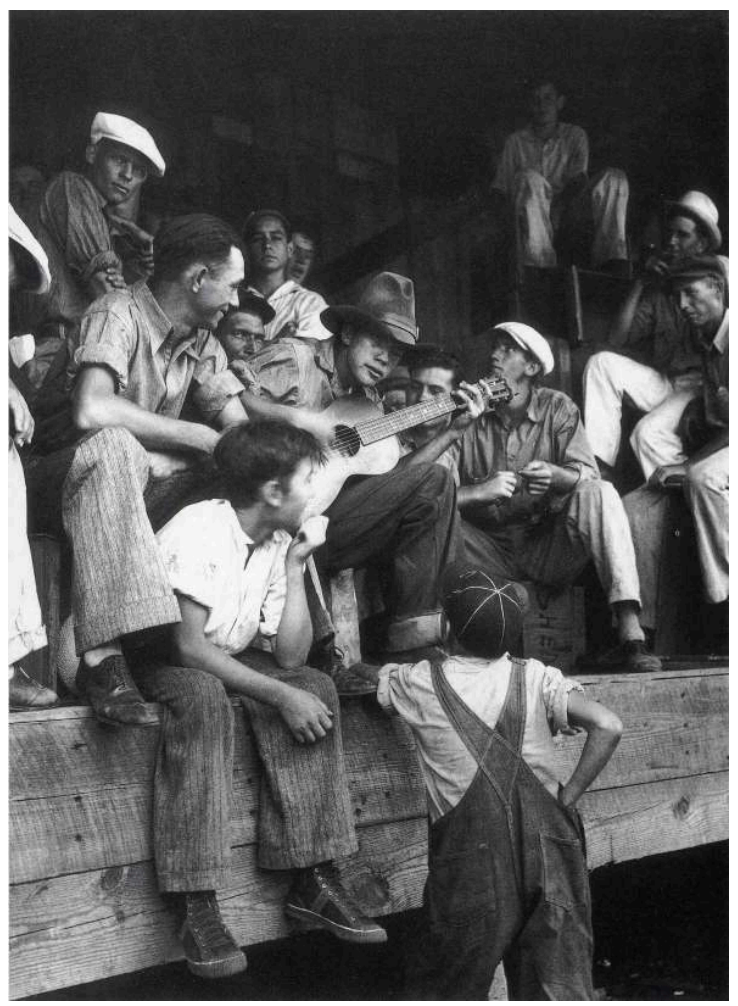

"Tomato packers recess, Copiah County, 1936," Photographs, p. 31, with the gracious permission of the Eudora Welty Foundation

1 As well as any photo I know, Eudora Welty here embodies music in sight. She has caught a moment of music as it ripples through these men. The music swirls around 
and through the casual grace of its listeners' lounging the way a clothesline of billowing laundry captures the shape of the wind.

2 There's a magic tension in the composition. The relaxed throw of these bodies and the loose flow of their clothes-the most unselfconscious arrangement possible-is set within a frame that seems so perfectly balanced, through such a strongly imaginative eye, that these men and boys seem as formally determined as the choreography of Busby Berkeley.

3 The photo is a charming testament to folk music. Welty shows a music that rises from within its particular culture, music born of, and of a piece with its listeners-the guitarist is literally encircled by his audience, as though he were the generative pistil in the heart of a flower-with no separation between performer and audience. And yet, at the same time, Welty's sense of irony is always active. She was capturing the end of what Sean Wilenz calls the "old, weird America" and its pre-electric folk during the rise of the recording industry, national radio broadcasting, and mass-media entertainment. In the pose of the guitar player, is there not the slightest mimic of the star? Is his expression and attitude-in the exact center of this folk culture-also not the face of the pop-music future?

INDEX

Subjects: Trans'Arts

\section{AUTHOR}

LOUIS MAZZARI

Bogazici University, Istambul 